sciendo

10.2478/abcsj-2021-0009

\title{
Proust in Transylvania: Smell and Memory in Romania
}

\author{
SEBASTIAN GROES \\ University of Wolverhampton \\ and \\ TOM MERCER \\ University of Wolverhampton
}

\begin{abstract}
"Christmas time as a child - dinner on Christmas day with my grandparents, parents and extended family members. My grandparents used to make sausages before Christmas and we would eat them on Christmas day during a festive dinner with extended family members." (45-54-year-old female)
\end{abstract}

"It reminds me of grandparents from the country" (45-54-yearold male)

"A family gathering at the countryside. It's Christmas and we are all eating and drinking ... My grandmother's kitchen in our countryside house." (18-24-year-old female)

"Putting meat to cure; we used to do that a lot when I was younger. My grandmother's place: we had a special place where we cured the meat and I used to carry the wood for the fire; we used specific types of wood depending on the type of meat." (25-34-year-old female)

"Christmas time with my family" (18-24-year-old female)

"Winter in my grandparents' house in the countryside." (25-34year-old female)

\section{Introduction}

The above lines are childhood memories described by participants in an interactive psychological experiment in response to the smell of cârnați, 
which are traditional Romanian sausages made with pork or mutton, chilli peppers and garlic. What is striking are the smell's associations with family and grandparents - and especially the grandmother. Indeed, for other smells that were tested, including țiică (Romanian plum brandy) and brânză de burduf (a salty Romanian cheese made from sheep milk) what was striking was the consistent connection to family - and in the case of cârnaţi a link with Christmas celebrations.

This experiment involved mapping the public's responses to a number of different smells, as well as to see what (childhood) memories those smells elicited. It was held in November 2019 during the Craving Planet Earth conference held at Lucian Blaga University of Sibiu, Romania. This event, organised as part of the Being Human Festival, took place at the Astra Library in Sibiu and followed up a larger research project that looks into the so-called Proust Phenomenon, which suggests that odours can reactivate strong, emotive childhood memories. Since 2018, the Wolverhampton team, consisting of the authors of this essay, had taken existing research into this phenomenon into a new direction: they wanted to know whether it would be possible to investigate which specific smells belong to a geographical territory by showing that inhabitants of a region would be more adept at identifying and describing those local smells. What's more, if smells trigger memories from one's past, it might be possible to also map specific (childhood) memories that are related to a specific locality. We had been launching a number of experiments in and around the Black Country, an area in the middle of England with a strong post-industrial heritage and working-class identity, to understand the validity of that hypothesis, but the public engagement event at which those experiments were held had another motive: the smell-memory experiments were used to promote smell awareness, an understanding of the importance of olfaction that in modern times has gone lost (see Groes and Francis 13). Below, the readers will find a detailed explanation, as well as the outcome, of the experiment; yet, first we will contextualise the (literary) history of experiments in olfaction. 


\section{The Proust Phenomenon in Context}

Strong smells can revive strong, emotive memories - a feature that has come to be known as the 'Proust Phenomenon.' Compared to other senses such as vision and hearing, odours have a privileged access to unlocking childhood memories (see Chu and Downes). The French writer Marcel Proust's work is at the start of this research. Proust was particularly interested in investigating selfhood and the role memory plays in identity, and his project became a decennia-long examination of his life. À la recherche du temps perdu (translated as In Search of Lost Time, 19131927), has a striking episode when Proust's middle-aged narrator, Marcel, sips a tea-spoon of lime-blossom tea mixed with crumbs of a petite madeleine cake. The taste and smell elicit memories from his childhood: they take him back to the old houses of the village where he grew up, to the streets where he was sent on errands, the squares and gardens, and, finally, to his aunt Léonie's bedroom where he would drink lime-blossom tea:

And as soon as I had recognized the taste of the piece of madeleine dipped in lime-blossom tea that my aunt used to give me [...] immediately the old grey house on the street, where her bedroom was, came like a stage-set to attach itself to the little wing opening on to the garden [...] all the flowers in our garden and M. Swann's park, the water-lilies on the Vivonne, and the good people of the village and their little dwellings and the church and all of Combray and its surroundings, all of this which is assuming form and substance, emerged, town and garden alike, from my cup of tea. (Proust 50)

Ever since the publication of In Search of Lost Time, psychologists and neuroscientists have tried to fathom and reproduce what came to be known as the Proust Phenomenon. Now we know that scents are better stimuli for evoking autobiographical memories compared to other stimuli because of the direct connections olfaction has with parts of the limbic system involved in generating emotion and memory (see De Bruijn et al.; Soudry et al. and Willander et al.). The neural basis for smell is unique (Smith 39). Smell is the only sense that circumvents the thalamic relay and has direct access to regions of the brain activated during emotional 
processing (the amygdala), long-term memory formation (the hippocampus) and higher order cognitive processing and evaluation (orbitofrontal cortex). It is this unusual neural set-up that has led many scientists and scholars to speculate about the special role olfaction plays in memory, emotion and higher order thinking.

The episode in Proust's novel shows us that (nonverbal) emotions and sensations take place before declarative memories. When Marcel drinks his tea, it takes the character a long time before the autobiographical, semantic memory (the story of a memory that you can narrate) develops into a detailed memory. The memories of Combray, its buildings and parks and, finally, Marcel's grandmother's house, take six pages to unfold. This suggests that, even though odours have a strong effect on the brain, retrieving memories is hard work. Memories start off as vague, amorphous sensations, and we only slowly retrieve more detailed, refined forms of reminiscence. This gradual process of memories unfolding can be explained because smells are hard to name and describe; olfaction is often described as the silent sense (Draaisma 16). Although odours can trigger emotive feelings that could become equally emotive memories, we have a hard time identifying smells. And we do not really know the veracity of memories evoked: especially because they are coloured by emotions, we cannot really know how truthful those memories are. Our brain is a black box that absorbs input and yields output (that is, our everyday subjective experience of the world), and we cannot properly know the exact electro-chemical processes that occur inside our grey matter. Ergo, we also cannot know what the exact status is of the memories that we retrieve. Scents are particularly good at evoking nostalgia - which will come as no surprise to readers of Proust, though the intricacies of the effect of olfaction on generating nostalgia are very detailed. And this nostalgia has many beneficial effects on people's mental well-being: "Scent-evoked nostalgia predicted higher levels of positive affect, self-esteem, self-continuity, optimism, social connectedness and meaning in life" (Reid et al. 157). The point is of course that nostalgia too colours our perception of the past, leading us away from a potential truth status of our memories of the past, but this does not necessarily matter: the mind is constantly editing and reworking 
(traumatic) events of the past to fit in to a life story with a happy ending that makes people feel good about their lives. This is one reason why writers of fiction are so attracted to engaging with the texture of memory in their work.

Although smells may be hard to identify, literary history suggests that writers have attempted to capture smell in the medium at their disposal - words. Perhaps most famously, Patrick Süskind's Das Parfum (1985) tells the story of the perfumer Jean-Baptiste Grenouille in eighteenth-century Paris whose obsession with smell leads to a series of murders. Throughout history, writers have been deeply interested in and trying to capture smell, from the "Sweet breathing Zephyrus" in Edmund Spenser's Prothalamion (1596) to T.S. Eliot's fascination by London's excremental emanations in The Waste Land (1922). In short, literature is the key to giving a voice to the silent sense - and it is interesting to note that one of the best-loved horror novels of all time, Bram Stoker's Dracula (1897), is particularly strong on understanding the role of smell in human behaviour.

\section{"There is peace in its smell": Dracula and Olfaction}

Our sense of smell is a key component in our behaviour and mental lives. Recent science has shown that there is a strong relationship between olfaction and depression (Kohli et al.), for instance. Smell is also related to our stress levels. Women feel calmer after being exposed to their male partner's scent. Conversely, a stranger's smell has the opposite effect, raising levels of cortisol, the stress hormone (Hofer et al.). Pheromones are important in women's sexuality: pheromones may be present in all bodily secretions but most attention has been geared toward axillary sweat, which contains the odorous 16-androstenes. One of these steroidal compounds, androstadienone, is present at much higher concentrations in male sweat and can be detected by women, albeit with wide variation in sensitivity. Upper-lip application of a pharmacological dose of androstadienone results in improved mood and heightened focus particularly to capture emotional information. A positive mood is known to facilitate women's sexual response, and increased focus improves 
sexual satisfaction. Some studies showed a beneficial effect of androstadienone on sexual desire and arousal, and some data indicates that 16-androstene pheromones, in particular androstadienone, play a beneficial role in women's mood, focus and sexual response, and perhaps also in mate selection.

Smell awareness is therefore crucial to our individual being and to our cultures. In modernity, we are living in societies subjected to a growing regime of hygiene, driven by a politico-capitalist elite and a powerful middle-class culture that promotes their socio-cultural values by means of a specific politics of smell, amongst others. Marginalised parts of the population, including the working classes, women and ethnic minorities have been subject to olfactory discrimination. The working classes were automatically associated with malodour, as cleanliness was metaphorically associated with social status. Historically, women have been told to artificially scent their bodies and, since 1915, shave their body hair with a view to covering up their body odour, which, although it ostensibly was deemed malodorous, was in fact attractive. Ethnic minorities have an equally ambiguous position in the olfactory imaginary as the Orientalising white male perception of the exoticised Other associated the Other with animals and uncleanliness. The white, maledominated heteronormative tradition of Humanism and the legacy of the Enlightenment - underpinned by the privileged position that made male sensory perception central and women's bodies and perception in a certain way invisible or at least marginal - have focused their dominance also via sensory ideological powerplay.

Dracula is a work of fiction not universally loved by Romanians for its offensive, Orientalising depiction of their country, though it excels at sensory exploration and investigation of the above mentioned ideological powerplay. Touch, taste and vision are all explored in detail throughout the story about the invading undead Count, but what strikes is the novel's keen interest in the power of olfaction. One of the arresting juxtapositions that the novel makes is between the smell of artificially cultivated flowers (a symbol of wealth and taste for the burgeoning bourgeoisie in the West during the later Victorian era) and garlic, the well-known protective device against vampires. Advised by an army of figures embodying 
masculine, modern rationalism including Dr Van Helsing and Dr Seward, Lucy Westenra's seduction by the sensuous stalker from Eastern Europe is hoped to be stopped by hanging garlic in the window and by wearing wreaths around her neck. Van Helsing notes that the wreaths are "medicines" (Stoker 140), yet Lucy finds that his "actions were certainly odd and not to be found in any pharmacopœia that I ever heard of" (Stoker 141). Whereas the Professor argues in heavily mythical overtones that the garlic flowers "smell so like the water of Lethe" (a river in the Greek underworld causing forgetfulness) that will "make your trouble forgotten," Westenra notes that "these flowers are only common garlic" (Stoker 140). The good doctor's aim is to use the pungent, acrid smell of the flowers as an instrument of repression: Westenra has fallen in love with Dracula, who visits her during the night in the shape of a bat, feasting on her blood. Stoker adeptly inverts real and metaphorical economies throughout the novel, and here the physical manifestations of her undiagnosed disease - an infection the source of which is unknown stands for Westenra's having fallen in love. Under the count's sexual spell, she has slowly cast her civilised manners aside, and, in overtly Freudian overtones, is taken over by unconscious drives and animal instincts. Whereas Dr Seward describes garlic as "those horrible, strongsmelling flowers" (Stoker 144), Lucy notes:

Somehow, I do not dread being alone to-night, and I can go to sleep without fear. I shall not mind any flapping outside the window. Oh, the terrible struggle that I have had against sleep so often of late; the pain of the sleeplessness, or the pain of the fear of sleep, with such unknown horrors as it has for me! How blessed are some people, whose lives have no fears, no dreads; to whom sleep is a blessing that comes nightly, and brings nothing but sweet dreams. Well, here I am to-night, hoping for sleep, and lying like Ophelia in the play, with "virgin crants and maiden strewments." I never liked garlic before, but to-night it is delightful! There is peace in its smell; I feel sleep coming already. Good-night, everybody. (Stoker 143)

The heavy allusions to Ophelia's suicide in Hamlet here evoke cruel irony: whereas the smell of garlic neutralises Westenra's unbalanced, love-struck mind, sleep is also clearly associated with death. 
Unconsciously, Westenra does not want to be cured - and she removes the garlic from her room. Carol Senf suggests that

Stoker spends proportionately more space on disgusting smells, an emphasis that distinguishes his writing from the plausible physical detail in evidence in realism. [...] Harker encounters the three vampire women in Dracula's castle and is initially intrigued by their voluptuousness until he detects "a bitter offensiveness, as one smells in blood" (69). Because Dracula is rarely on stage, readers see him less through his relationships with the other characters than through the odor of a corrupt and moldering body that he leaves behind. At Carfax, Harker describes the experience: "But as to the odour itself, how shall I describe it? It was not alone that it was composed of all the ills of mortality and with the pungent, acrid smell of blood, but it seemed as though corruption had become itself corrupt" (290). While the odors (and also Dracula's lack of language, pointed ears, and sharp, canine teeth) remind readers of Dracula's connection to animals, Stoker's descriptions of Lucy remind readers that she, like the women in Dracula's castle, is a predator. (66)

By showing women's quest for emancipation through domination - the undead state does not discriminate between the genders - Stoker is playing subversively with the political, gendered role of smell in the eighteenth century and Victorian times: the smelling salt was commonly used to revive women after they had fainted in distress, but the smelling bottle itself had become a complex prop, as novelists Henry Mackenzie and Jane Austen had shown. As Emily C. Friedman shows, when smelling salts fail to bring a woman back to consciousness, this may suggest not an "insensitivity to stimulus, but overwhelming sensibility" (66). In Mackenzie's The Man of the World (1773), a character fainting when hearing her brother may have been hung is revived by a doctor using smelling salts: "While the remedy is effective, it is read in context as harsh, given its association with a physician who immediately recommends that she be drained of excess blood, wielding bloody, rusty lancets, and eager more for the guinea he is given than for the well-being of the patient before him" (Friedman 65). In short, Dracula's bloodsucking itself is associated with a common medical practice bloodletting, which was only stopped around 1935.

The smell of blood itself becomes an important focus in Stoker's investigation of modernity. As Eszter Muskovits suggests, Dracula's 
obsession with, and fetishization of, blood "becomes the exclusive object of sexuality. The haematophiliac has an erotic attraction to the taste, sight or smell of blood. Haematodipsia is a stronger form of this disease. People gain their whole sexual satisfaction from blood, that is "what coitus is to the lover, the bite and the sucking is to the haematodipsiac" (Muskovits). Stoker's novel is, then, an attack on the 'modern' medical profession and its practices, and a celebration of the senses - and the power of smell in the regulation of human behaviour especially. Research from 2015 has suggested that the scent of blood is a key driver of both animal and human behaviour. The odorant trans-4,5-epoxy-(E)-2-decenal, which evokes the typical metallic, bloodlike scent in humans, has been shown to have a remarkable effect on the behaviour of large carnivores. Nilsson et al. showed that this "single blood odor component can be as efficient in eliciting behavioral responses in large carnivores as the odor of real blood." Moran et al. hypothesized that the "scent of blood, with its association with injury, danger, death, and nutrition will be a critical cue activating fundamental motivational systems relating to either predatory approach behaviour or prey-like withdrawal behaviour, or both." What is more, women seem to be more sensitive to the smell of blood and, although both men and women have positive and negative emotional responses to the blood odour, "negative ratings in women have a strong arousal component," dependent on their menstrual cycle (Moran et al.). Stoker's novel suggested all this over a century ago.

Proust in Transylvania: the Romanian Smell and Memory Experiment

To investigate the connection between smell and memory in the Romanian region of Transylvania, an interactive experiment was designed and informed by prior work into autobiographical odour memory. However, unlike past psychological research into the Proust Phenomenon, this experiment aimed to assess the effects of specific smells on memory recall in relation to a specific region; various experiments by the authors had been undertaken in the Black Country in 2018 and 2019 for the Being Human Festival. This new design, therefore, moves away from past work 
that has focussed on comparing smells against other memory cues (e.g. words or pictures), and towards an assessment of smell itself. The experiment compared smells belonging to the Transylvania region against more generic smells, to see which odours prompted recall. It also examined the participants themselves, particularly concerning where they grew up and how this related to autobiographical odour memory.

\section{Participants}

Forty-seven participants took part in the experiment, including 36 women and 11 men. Participants were either delegates of the East-West Cultural Passage Conference "Craving Planet Earth" or members of the general population, and quite a few from the Transylvanian town Sibiu. They took part during the "Proust in Transylvania" event at the conference. Participants varied in age (see Table 1) and the majority (29) were currently living in Romania. Of the remaining 18 participants, 13 were from other European countries, three were from the USA and two were from Asia. All participants provided written informed consent before completing the task.

Table 1: Number of Participants According to Age Category

\begin{tabular}{ll}
\hline Age Category & Number \\
\hline $18-24$ & 9 \\
$25-34$ & 9 \\
$35-44$ & 12 \\
$45-54$ & 8 \\
$55-64$ & 7 \\
$65+$ & 2 \\
\hline
\end{tabular}

Materials

Eight smells were created for the experiment and contained within small numbered tubs. The contents of each tub were disguised using cotton pads. There were four general smells (bubble bath, paint, cinnamon and disinfectant) and four smells specific to Romania. These included cozonac (a type of sweet bread), brânză de burduf (a type of cheese), cârnați (sausage) and țuică (Romanian plum brandy). 
Responses to the smells were collected in a booklet, which included a demographic questionnaire. For each smell, there was a response sheet divided into two sections: identifying/rating the smell and describing/ rating memories elicited by the smell. For smell identification, there was a space for participants to write down the identity of the smell and then rate its familiarity, intensity and pleasantness. These ratings were on a sevenpoint scale, varying from 1 ("Not at all") to 7 ("Very"). The memory/ description part of the response sheet included space for participants to briefly describe the event being recalled and date it. The memory then had to be rated on its significance, detail and pleasantness, using the same seven-point scale as outlined above. The final question in this section asked whether participants could associate the memory with any specific place/location. The last page of the booklet required participants to list any smells that they associated with Romania, and any memories connected to those smells.

\section{Design and Procedure}

The event was run on 8 November 2019 and lasted approximately 45 minutes. Participants were introduced to the task and given an opportunity to ask questions. Those willing to take part were then asked to complete a consent form before moving onto the main task, using the eight smells and the booklet. Participants were seated at tables in small groups but were asked to complete the task independently.

For each smell, participants selected the tub, opened it and smelt the contents. They then had to try and identify the smell and rate it. If the smell elicited a memory, participants wrote a brief description of the memory, estimated their age at the time the remembered event happened, and rated the memory on its significance, detail and pleasantness. It was expected that all participants would be able to complete the smell identification/rating, but they were told to ignore the memory identification/rating if they did not recall any event. This procedure was then repeated for all smells. Importantly, the identity of the smells was not revealed at this stage. 


\section{Data Analysis}

The analysis aimed to compare Romanian and non-Romanian participants. Typically, the country where participants were currently living matched where they had grown up, with two exceptions. However, as there is an important link between childhood memory and smell (Larsson et al.), participants were classified as Romanian or non-Romanian based on where they had grown up. The original intention was to collapse smells into specific categories, but as there was some missing data, the analysis focused on individual smells.

\section{Data Scoring}

Table 2: Data Scoring Method for Each Smell

\begin{tabular}{|c|c|c|}
\hline Smell & $\begin{array}{l}\text { Correct Answers } \\
\text { (Scoring 1 Point) }\end{array}$ & $\begin{array}{l}\text { Partly Correct Answers } \\
\text { (Scoring 0.5 Points) }\end{array}$ \\
\hline $\begin{array}{l}\text { Cozonac } \\
\text { (Romanian sweet bread) }\end{array}$ & $\begin{array}{l}\text { Cozonac / sweet bread / } \\
\text { cake }\end{array}$ & $\begin{array}{l}\text { Bakery-related/baking, other } \\
\text { cakes/sweet pies, bread, } \\
\text { general fruit-related smells }\end{array}$ \\
\hline Bubble bath & $\begin{array}{l}\text { Bubble bath / soap / } \\
\text { shampoo }\end{array}$ & $\begin{array}{l}\text { Cleaning-related products, } \\
\text { hand creams, baby-related } \\
\text { cleaning products }\end{array}$ \\
\hline Paint & Paint & $\begin{array}{l}\text { Paint remover, turps, } \\
\text { chemical-related smells }\end{array}$ \\
\hline $\begin{array}{l}\text { brânză de burduf } \\
\text { (Romanian cheese) }\end{array}$ & Cheese & $\begin{array}{l}\text { Dairy-related (e.g. milk, } \\
\text { yoghurt) }\end{array}$ \\
\hline Cinnamon & Cinnamon & Broad mention of spices \\
\hline $\begin{array}{l}\text { cârnați } \quad \text { (Romanian } \\
\text { sausage) }\end{array}$ & $\begin{array}{l}\text { Sausage, salami (and other } \\
\text { variants of sausage) }\end{array}$ & Other meats (e.g. bacon) \\
\hline $\begin{array}{l}\text { țică (Romanian plum } \\
\text { brandy) }\end{array}$ & $\begin{array}{l}\text { tuică, plum brandy, } \\
\text { brandy }\end{array}$ & $\begin{array}{l}\text { General alcohol reference, } \\
\text { other types of alcohol (e.g. } \\
\text { wine, whisky) }\end{array}$ \\
\hline \multirow[t]{2}{*}{$\begin{array}{l}\text { Anti-septic/disinfectant } \\
\text { (Dettol) }\end{array}$} & $\begin{array}{l}\text { Anti-septic, disinfectant, } \\
\text { TCP, Dettol }\end{array}$ & $\begin{array}{l}\text { Medical-related } \\
\text { smells/ointments }\end{array}$ \\
\hline & & $\begin{array}{l}\text { menthol, health-related } \\
\text { creams) }\end{array}$ \\
\hline
\end{tabular}

Participants were scored on their ability to identify each smell. If participants correctly identified the smell, they received one point. If their answer was broadly accurate, they received half a point. Incorrect or 
missing answers received a score of zero. An overview of the scoring method is shown in Table 2.

For the memory responses, participants were classed as either recalling or not recalling a memory for each smell. The age of the remembered event was then either classified as a memory from childhood (up to 11 years of age), a memory from adolescence (12-17 years of age), a memory from adulthood (18+ years of age) or a general memory. The latter referred to memories that reflected broad themes/events and were not tied to a specific age. If participants did not describe a memory but still provided the ratings, these were discarded as it was unclear if an actual memory was being rated.

\section{Smell Identification}

Data were not normally distributed, and, given that some participants did not complete responses for every smell, reducing the sample size, the nonparametric Mann-Whitney $U$ test was used to compare identification for each smell in the Romanian and non-Romanian participants (see Table 3). Scores could be 0 (incorrect), 0.5 (partially correct) or 1 (correct) for each smell.

Table 3: Median (and Interquartile Range) Identification of Each Smell

\begin{tabular}{llll}
\hline Smell & Romanian & Non-Romanian & Mann-Whitney U \\
\hline Cozonac & $0(0.5)$ & $0(0.5)$ & $U=185, p=.739$ \\
Bubble bath & $1(0.5)$ & $1(0.5)$ & $U=192, p=.357$ \\
Paint & $0.5(1)$ & $0(1)$ & $U=228, p=.697$ \\
Brânză de burduf & $0.5(1)$ & $0(0.5)$ & $U=169, p=.124$ \\
Cinnamon & $1(0)$ & $0.5(1)$ & $U=162, p=.007^{*}$ \\
Cârnați & $1(0.5)$ & $0.25(1)$ & $U=136.5, p=.004^{*}$ \\
Țuică & $0.75(0.5)$ & $0.5(0.5)$ & $U=189, p=.101$ \\
Disinfectant & $0(0.5)$ & $0.5(1)$ & $U=123, p=.004^{*}$ \\
\hline
\end{tabular}

Participants from Romania were significantly better at identifying the Romania-specific smell of cârnați (sausages), but also the general food smell cinnamon. Conversely, non-Romanian participants were better at identifying the smell of disinfectant. None of the other comparisons were significant. 


\section{Smell Ratings}

Romanian and non-Romanian participants were then compared on their ratings to each smell, again using the Mann-Whitney U test. Firstly, familiarity ratings were explored and are shown in Figure 1. Two differences were found, with the Romania-specific smells of brânză de burduf ( $U=123, p=.044)$ and cârnați $(U=118.5, p=.003)$ being rated as significantly more familiar in the Romanian than non-Romanian participants.

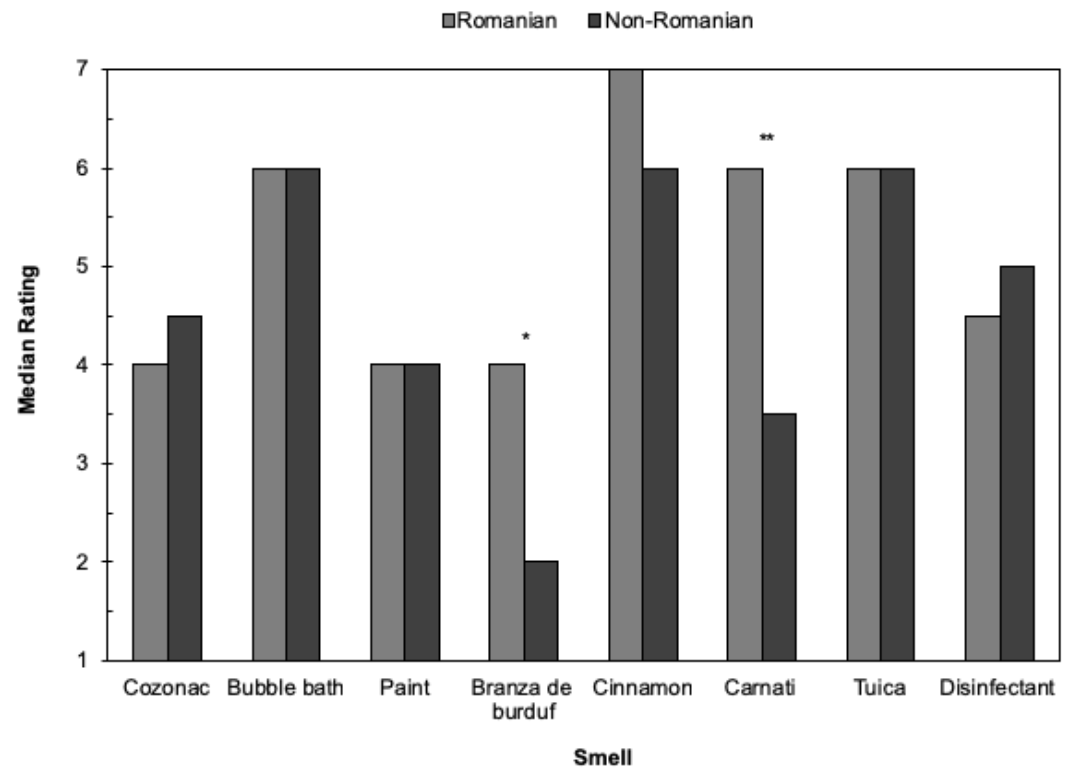

Figure 1. Median familiarity ratings according to smell for Romanian and nonRomanian participants. $*=p<0.05 ; * *=p<.01$.

Next, smell intensity ratings were examined (see Figure 2). Only one difference was found, with Romanians rating the Romania-specific smell of țuică as significantly more intense than non-Romanians ( $U=100, p<$ $.001)$. 


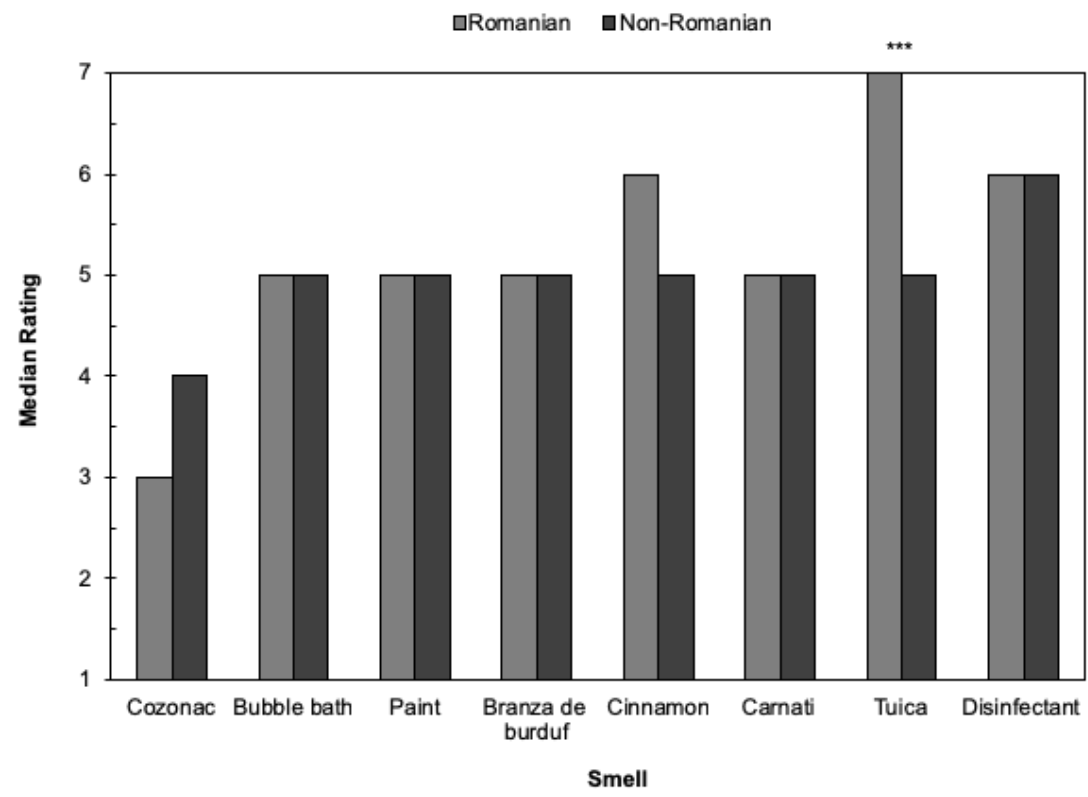

Figure 2. Median intensity ratings according to smell for Romanian and nonRomanian participants. $* * *=p<.001$.

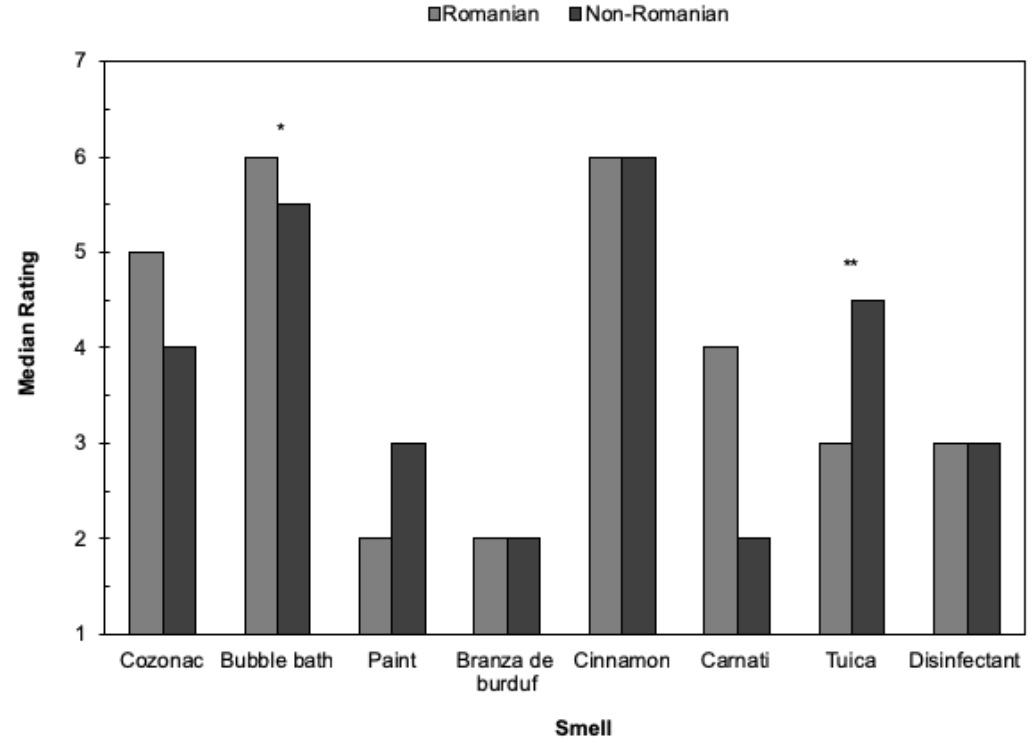

Figure 3. Median pleasantness ratings according to smell for Romanian and nonRomanian participants. $*=p<0.05 ; * *=p<.01$. 
Finally, smell pleasantness was explored (see Figure 3). The smell of bubble bath was rated as more pleasant in Romanian than non-Romanian participants $(U=197, p=.041)$, whereas non-Romanians rated the smell of țuică as more pleasant than Romanians ( $U=129, p=.005)$.

\section{Memory Recall}

Table 4: Number of Romanian and Non-Romanian Participants Recalling/Not Recalling Memories in Response to Three Smells

\begin{tabular}{llll}
\hline Smell & & \multicolumn{2}{l}{ Participant group } \\
\cline { 3 - 3 } \cline { 3 - 3 } & Romanian & Non-Romanian \\
\hline Paint & $19 / 8$ & $5 / 13$ \\
Brânză de burduf & $12 / 13$ & $3 / 15$ \\
Cârnați & $22 / 6$ & $6 / 12$ \\
\hline
\end{tabular}

For each smell, participants were classed as either having recalled or not recalled a memory. A Chi-Square test of independence was then used to check the association between the recall of a memory (recalled vs. not recalled) and participant group (Romanian vs. non-Romanian) for each smell. Significant associations between memory recall and participant group were found for the smells of paint $\left(x^{2}[1]=7.87, p=.005\right)$, brânză de $\operatorname{burduf}\left(x^{2}[1]=4.52, p=.033\right)$ and cârnați $\left(x^{2}[1]=9.41, p=.002\right)$ (see Table 4). Romanian participants were more likely than not to recall a memory to the smells of paint and cârnați, whereas non-Romanian participants were less likely to recall a memory to these odours. In contrast, Romanian participants were equally split in their memory recall for brânză de burduf, whereas very few non-Romanian participants recalled a memory for this smell. No other significant associations were found.

\section{Age for Recalled Event}

When participants recalled a memory and were able to date it, the age at which the event was formed was categorised, as outlined above. For the purposes of this analysis, memories were classed as either childhood or non-childhood, due to the low numbers in the adolescence and 
general/across periods categories. The Chi-Square test of independence was then used, this time exploring the association between participant group and age category for each smell. Only one significant association was found, for the smell of tuică, $x^{2}(1)=6.86, p=.009$. While nonRomanian participants usually dated memories evoked by țuică to adulthood, Romanian participants were equally divided between childhood and non-childhood memories (see Table 5). No other associations were found, though the sample size for these analyses was often low, as it was only based on those who recalled memories.

Table 5: Number of Romanian and Non-Romanian Participants Recalling Childhood and Non-Childhood Memories in Response to țuică

\begin{tabular}{llll}
\hline Memory Type & & Participant Group & \\
\cline { 4 - 4 } Childhood memory & & Romanian & Non-Romanian \\
Non-childhood memory & & 9 & 1 \\
\hline
\end{tabular}

\section{Ratings of the Memory, Describing the Past}

Where memories were recalled, participants were asked to rate it on its significance, detail and pleasantness. As these ratings were only available for those who could retrieve a memory, some of the conditions had very few participants (e.g. five or less). Given this limitation, these data were not further explored.

The numerical data outlined above revealed statistical connections between region-specific smells and memories, but further exploration of the written responses offered deeper insights into the quality of memories recalled. While not all memories were recalled in depth, there were plentiful cases of vivid and detailed responses, even though some memories dated to childhood and may have been decades old. As in the Black Country experiment, a very common theme was family - which is a connection anticipated by Proust's description of the madeleine effect, which brings him back to his grandmother - a figure abundantly present in the Romanian experiment as well. For example, in response to the smell of paint, one Romanian participant stated, "The smell reminds me of the moments I, together with my family, painted our cottage which is at the 
countryside ... I associate this memory with my grandparents' village where we have a cottage." The smell of paint helped other Romanian participants recall family members. For example, "I recall the time when my father would paint the walls of the rooms in the house," "[I remember] the time my grandmother painted over my TURBO gum sticker collection which I had put up on the inside of her pantry door" or "[I remember] my Dad repainting stuff."

While the smell of paint was used as a region-general odour, some of the Romania-specific smells also elicited memories with a strong connection to family. For example, after experiencing the smell of brânză de burduf, one Romanian participant wrote: "It smells like something my grammy used to purchase and I remember I did not like that back then also ... I associate this smell with my grandparents' house and village." This shows that location memory - like a family member's home - can be prompted by specific smells.

A similar theme emerged in response to the smell of țuică in other Romanian participants. For example, "The smell makes me remember the meetings with my grandfather and his friends from the village. Also, the Christmas time when all my family were gathered." Another Romanian participant recalled family meals: "Meals in the houses of grandparents and relatives. Ţuică used to accompany the lunches and dinners during childhood and while I was a teenager. I always associate the smell with family members (grandfather, father, uncles, older cousins)."

Similar responses were recorded for the Romania-specific cârnați smell, with memories of grandparents being particularly common for Romanian participants. For instance, "This smell [reminds] me of that time before Christmas at my grandparents! My grandma used to cook sausages all the time during winter" and "It reminds me of grandparents from the country." Interestingly, the smell of cârnați was often connected to Christmas in the Romanian participants, as is clearly seen in these examples: "I remember the time when we would sacrifice the pig for Christmas and make sausages out of its meat ... The weather would always be cold, maybe even snowy, because it usually happens in winter," "Christmas time as a child - dinner on Christmas day with my grandparents, parents and extended family members. My grandparents 
used to make sausages before Christmas and we would eat them on Christmas day during a festive dinner with extended family members" and "[I remember] a family gathering at the countryside. It's Christmas and we are all eating and drinking ... My grandmother's kitchen in our countryside house."

Odours can therefore evoke memories not just of specific, limited events, but of important people and places from the past. Yet only specific smells may be capable of unlocking these autobiographical memories.

\section{Conclusions}

The data analysis yields some interesting, statistically significant findings:

- Romanian participants were better at identifying the smells of cârnați (sausages) and cinnamon than non-Romanian participants. Conversely, non-Romanian participants were better than Romanian participants at identifying the smell of disinfectant.

- Romanian participants rated the smells of brânză de burduf and cârnați as more familiar than non-Romanian participants.

- Romanian participants rated the smell of țuică as more intense than non-Romanian participants.

- Romanian participants rated the smell of bubble bath as more pleasant than non-Romanian participants, whereas non-Romanian participants rated the smell of țuică as more pleasant than Romanian participants.

- Romanian participants were more likely to recall memories than not in response to the smells of paint and cârnați, whereas nonRomanians showed the opposite pattern. In addition, Romanian participants were equally divided in recalling or not recalling memories in response to the smell of brânză de burduf, whereas very few Romanians could recall memories for this smell.

- Non-Romanians generally recalled non-childhood memories in response to the smell of țuică, whereas Romanians were similarly split in the recall of childhood and non-childhood memories. 
When examining the written description of the recalled event, family members and (familiar, often familial) locations had an important place within the memories, but certain smells were better at evoking these memories than others. These findings support our early findings in research into Black Country smells and associated (childhood) memories, highlighting the value of exploring region-specific smells. This new field will enable us to understand better how smell works, but might provide innovative avenues in exploring how selfhood, memory, identity and location are inextricably linked by the senses. It not only highlights the importance of a focus on the senses that are often overlooked in scientific research, but it could potentially help contribute to offer new pathways in treatments of mental illness and dementia. Sensory exploration of placeidentity will also contribute to the cultivation of smell awareness, which will help, we hope, the public become more conscious of olfactory practices within modern culture. As our analysis of Dracula has shown, it is especially literature that - as the most refined exploration of human consciousness and experience - has a privileged role in this process. This is not only because literature is the medium that is able to synergistically unite disparate disciplines that would otherwise be disconnected, but also because it affords us the endlessly probing creative imagination to find ways of expressing phenomena that are seemingly difficult to verbalise, such as smells. Literature gives the silent sense a voice.

\section{Works Cited}

Chu, Simon, and John J. Downes. “Odour-Evoked Autobiographical Memories: Psychological Investigations of Proustian Phenomena." Chemical Senses 25.1 (2000): 111-116.

De Bruijn, Maaike J., and Michael Bender. “Olfactory Cues Are More Effective than Visual Cues in Experimentally Triggering Autobiographical Memories." Memory 26.4 (2018): 547-558.

Draaisma, Douwe. Why Life Speeds Up as You Grow Older. Cambridge: Cambridge UP, 2004.

Friedman, Emily C. Reading Smell in Eighteenth-Century Fiction. Buckness: Buckness UP, 2016.

Groes, Sebastian, and R. M. Francis, eds. Smell, Memory, and Literature in the Black Country. New York: Palgrave, 2021. 
Hofer, M.K., H.K. Collins, A.V. Whillans, and F.S. Chen. "Olfactory Cues from Romantic Partners and Strangers Influence Women's Responses to Stress." Journal of Personality and Social Psychology 114.1 (2018): 1-9.

Kohli, P., et al. "The Association Between Olfaction and Depression: A Systematic Review." Chemical Senses 41.6 (July 2016): 479-86. Web. 30 June 2020.

Larsson, Maria, et al. "Olfactory LOVER: Behavioral and Neural Correlates of Autobiographical Odor Memory." Frontiers in Psychology. 11 Apr. 2014.

Moran, James K., et al. "The Scent of Blood: A Driver of Human Behavior?" PLOS ONE 23 Sept. 2015. Web. 1 July 2020.

Muskovits, Eszter. "The Threat of Otherness in Brain Stoker's Dracula." Trans Revue de littérature générale et comparée 10 (2010). Web. 30 June 2020.

Nilsson, S., et al. "Behavioral Responses to Mammalian Blood Odor and Blood Odor Component in Four Species of Large Carnivores." PLOS ONE 10 Nov. 2014. Web. 13 June 2020.

Proust, Marcel. The Way by Swann's. Trans. Lydia Davis. London: Penguin, 2003.

Reid, C.A., et al. "Scent-evoked Nostalgia.” Memory 23.2 (2014): 155-166.

Senf, Carol. "Realism, Horror and the Gothic in Dracula and Thomas Hardy's 'The Fiddler of the Reels'." Palgrave Communications 3.17083 (2017). Web. 15 July 2020.

Soudry, Y., et al. "Olfactory System and Emotion: Common Substrates." European Annals of Otorhinolaryngology, Head and Neck Diseases 128.1 (Jan. 2011): 18-23.

Smith, Barry C. "Proust, the Madeleine and Memory." Memory in the TwentyFirst Century. Ed. Sebastian Groes. London: Palgrave, 2016. 38-41.

Stoker, Bram. Dracula. London: Penguin, 2003.

Willander, Johan, and Maria Larsson. "Olfaction and Emotion: The Case of Autobiographical Memory.” Memory \& Cognition 35.7 (Oct. 2007): 16591663. 